\title{
MENGOPTIMALKAN SUPERVISI OBSERVASI KELAS SEBAGAI UPAYA PENGAWAS SEKOLAH UNTUK MENINGKATKAN KEMAMPUAN GURU DALAM MENGELOLA PEMBELAJARAN PENDEKATAN KOOPERATIF PADA SEKOLAH BINAAN"
}

\author{
Ana Misfasiroh Hayati \\ ana.pengawaslamongan@yahoo.co.id \\ Pengawas SMP Dinas Pendidikan Kab. Lamongan
}

\begin{abstract}
ABSTRAK
Penelitian ini bertujuan untuk meningkatkan kemampuan guru dalam mengelola pembelajaran menggunakan pendekatan kooperatif khususnya model Think Pair Share melalui supervisi observasi kelas. Penelitian ini menggunakan rancangan penelitian tindakan sekolah, dengan 3 siklus, yang masing-masing siklus terdiri 4 kegiatan, yaitu perencanaan, pelaksanaan, pengamatan, dan refleksi. Penelitian Tindakan ini dilaksanakan di 5 sekolah binaan, yaitu SMPN 1 Karanggeneng, SMPN 1 Turi, SMPN 2 Lamongan, SMP NU Simo Karanggeneng, dan SMP Wahid Hasyim Maduran semester ganjil tahun pelajaran 2017/2018 sebanyak 3 siklus dengan mengambil subyek penelitian 5 orang guru di 5 Sekolah Binaan. Setelah dilakukan penelitian tindakan kelas selama tiga kali putaran (3 siklus), maka Teknik supervisi observasi kelas yang dilakukan peneliti/pengawas sekolah, mampu meningkatkan kemampuan para guru Sejarah di 5 Sekolah Binaan kabupaten Lamongan dalam mengelola pembelajaran kooperatif model Think Pair Share. Hal ini dibuktikan dengan kemampuan guru pada siklus I yang hanya 51,6 \% naik menjadi 72,4 \% pada siklus II, dan menjadi $86,6 \%$ pada siklus III. Disamping itu pendekatan Pembelajaran dengan kooperatif model Think Pair Share memiliki dampak positif dalam meningkatkan prestasi belajar siswa yang ditandai dengan peningkatan ketuntasan belajar siswa dalam setiap siklus, yaitu siklus I $(70,45 \%)$, siklus II $(81,82 \%)$, dan siklus III $(88,64 \%)$. Disamping itu pendekatan pembelajaran kooperatif model Think Pair Share dapat meningkatkan motivasi belajar siswa yang ditunjukkan dengan rata-rata jawaban siswa yang menyatakan bahwa siswa tertarik dan berminat dengan model pembelajaran kooperatif Think Pair Share sehingga mereka menjadi termotivasi untuk belajar. Untuk itulah peneliti menyarankan agar Pengawas sekolah diharapkan sering melakukan supervisi observasi kelas untuk perbaikan pembelajaran yang dilakukan oleh para guru di Sekolah Binaan, serta para guru Sejarah atau guru mata pelajaran lainnya hendaknya menggunakan model pendekatan ini dalam pembelajaran.
\end{abstract}

Kata Kunci: Supervisi Observasi Kelas; Kemampuan Guru Dalam Mengelola Pembelajaran, Pendekatan kooperatif.

\section{PENDAHULUAN}

Pebelajaran saat ini tidak lagi mengutamakan pada penyerapan melalui pencapaian informasi, tetapi lebih mengutamakan pada pengembangan kemampuan dan pemrosesan informasi. Untuk itu aktifitas peserta didik perlu ditingkatkan melalui latihan-latihan atau tugas-tugas dengan bekerja kelompok dan menjelaskan ide-ide pada orang lain. (Hartoyo, 2010: 24). Langkah-langkah tersebut memerlukan aktif dari siswa. Untuk itu perlu ada pembelajaran yang melibatkan siswa secara langsung dalam pembelajaran. Adapum metode yang dimaksud adalah metode pembelajaran kooperatif. Pembelajaran kooperatif adalah suatu pengajaran yang melibatkan siswa dalam kelompok-kelompok untuk menetapkan tujuan bersama. (Felder, 2004:2).

Pembelajaran kooperatif lebih menekankan interaksi antar siswa. Dari sini siswa akan melakukan komunikasi aktf dengan sesama temannya. Dengan komunikasi tersebut diharapkan siswa dapat menguasai materi pelajaran dengan mudah karena "siswa lebih mudah memahami penjelasan dari kawannya dibanding penjelasan dari guru karena taraf pengetahuan serta pemikiran mereka lebih sejalan dan sepadan". (Sulaiman dalam Wahyuni 2011: 2). Penelitian juga menunjukkan bahwa pembelajaran 
kooperatif memliki dampak yang amat positif terhadap siswa yang rendah hasil belajarnya. (Nur, 2006:2).

Pete Tschumi dari Universitas Arkansas Little Rock memperkenalkan suatu ilmu pengetahuan pengantar pelajaran komputer selama tiga kali, yang pertama siswa bekeraja secara individu, dan dua kali secara kelompok. Dalam kelas pertama hanya $36 \%$ siswa yang mendapat nilai $\mathrm{C}$ atau lebih baik, dan dalam kelas yang bekerja secara kooperatif ada $58 \%$ dan $65 \%$ siswa yang mendapat nilai $\mathrm{C}$ atau lebih baik. (Felder, 2004:14). Pada sisi lain, Boardman (1967) mengemukakan bahwa tanggungjawab kepala sekolah dan juga pengawas sekolah sebagai supervisor (pembina) guru-guru mencakup kegiatan dalam membimbing guru agar dapat memahami lebih jelas tentang masalah-masalah dan kebutuhan murid dan kemudian membantu menyelesaikannya, membantu guru mengatasi kesulitan mengajarnya, memberi bimbingan dengan cara bijaksana kepada guru baru melalui proses orientasi, membantu guru dalam memperoleh kecakapan mengajar yang lebih baik dengan menggunakan berbagai metode mengajar, membantu guru memperkaya pengalaman belajar sehingga mampu menciptakan suasana pengajaran kondusif, membantu guru agar mereka lebih mengerti tentang makna media pengajaran yang dipergunakannya, menumbuhkan moral yang tinggi dalam pelaksanaan tugas sekolah pada seluruh staf, dan memberi layanan kepada guru agar ia dapat menggunakan seluruh kemampuannya dalam melaksanakan tugas

Berdasarkan paparan tersebut di atas maka peneliti ingin mencoba melakukan penelitian dengan judul "Mengoptimalkan Supervisi Observasi Kelas Sebagai Upaya Pengawas Sekolah Untuk Meningkatkan Kemampuan Guru Dalam Mengelola Pembelajaran pendekatan kooperatif Pada Sekolah Binaan". Sesuai dengan permasalahan di atas, penelitian ini bertujuan untuk: Meningkatan kemampuan guru di sekolah binaan dalam mengelola pembelajaran dengan pendekatan kooperatif melalui supervisi observasi kelas.

\section{METODE}

Penelitian Tindakan Sekolah (PTS) ini dilaksanakan di sekolah binaan peneliti sebagai pengawas sekolah, yaitu di 5 (lima) SMP di kabupaten Lamongan. Subyek penelitian adalah para guru IPS kelas VIII dari 5 SMP wilayah binaan kabupaten Lamongan, yaitu:

Tabel 1. Guru IPS kelas VIII Wilayah Binaan Kab. Lamongan

\begin{tabular}{lll}
\hline No & Nama Sekolah & Nama Guru Sebagai Subyek Penelitian \\
1 & SMPN 1 Karanggeneng & Rohmi Latifah, S.Pd. \\
2 & SMPN 1 Turi & Hariyanto, S.Pd. \\
3 & SMPN 2 Lamongan & Atika Karmiati, S.Pd. \\
4 & SMP NU Simo Karanggeneng & Dra. Siti Husnul Chotimah, S.Pd. \\
5 & SMP Wahid Hasyim Maduran & Endang Titik Suryawati, S.Pd. \\
\hline
\end{tabular}

Sugiarti, $2007: 6$ ), yaitu berbentuk spiral

Sesuai dengan jenis penelitian yang dipilih, yiatu penelitian tindakan, maka peneliti ini meggunakan model penelitian tindakan dari Kemmis dan Taggart (dalam dari siklus yan satu ke siklus yang berikutnya. Setiap siklus meliputi Planning (rencanan), Action (tindakan), Observation (pengamatan), dan Refleksi. Langkah pada siklus berikutnya adalah perencanaan yang sudah direvisi, tindakan, pengamatan, dan 
refleksi. Sebelum masuk siklus 1 dilakukan tindakan pendahuluan yang berupa identifikasi permasalahan. Penelitian ini dilakukan siklus demi siklus sesuai dengan konsep penelitian tindakan, direncanakan ada 3 sampai 4 siklus untuk tiap-tiap sekolah. Instrumen yang digunakan dalam penelitian ini terdiri dari: (1) Lembar observasi kegiatan belajar mengajar. (2) Lembar observasi pengelolaan pembelajaran kooperatif metode Think Pair Share, untuk mengamati kemampuan guru dalam mengelola pembelajaran. (3) Lembar observasi aktivitas siswa dan guru, untuk mengamati aktivitas siswa dan guru selama proses pembelajaran. (4) Angket motivasi terhadap pembelajaran kooperatif model Think Pair Share. Angket ini digunakan untuk mengetahui apakah siswa-siswa tersebut menyenangi model pembelajaran yang ditawarkan penulis. Data-data yang diperlukan dalam penelitian ini deperoleh melalui observasi pengelolaan pembelajaran kooperatif model Think Pair Share, observasi aktifitas siswa dan guru, dan angket motivasi siswa.

\section{HASIL PENELITIAN DAN PEMBAHASAN}

Data lembar observasi diambil dari dua pengamatan yaitu data pengamatan pengelolaan pembelajaran koooperatif model Think Pair Share yang digunakan untuk mengetahui perkembangan tingkat kemampuan guru dari siklus ke siklus dalam mengelola pembelajaran, dan data pengamatan aktivitas siswa dan guru pada waktu pelaksanaan pengelolaan pembelajaran pendekatan kooperatif model 'Think Pair Share. Angket motivasi siswa digunakan untuk mengetahui pengaruh motivesi belajar siswa setelah diterapkan pembelajaran koooperatif model Think Pair Share.

\section{Siklus I}

1. Tahap Perencanaan

Kegiatan yang dilaksanakan pada siklus ini adalah peneliti merencanakan melaksanakan supervisi observasi kelas, dengan terlebih dahulu memberi penjelasan kepada guru tentang konsep dan tahapan penerapan pembelajaran pendekatan kooperatif model 'Think Pair Share yang harus dilakukan oleh guru. Selanjutnya guru melaksanakan tahapan yang disarankan oleh peneliti, yaitu merencanakan tindakan pembelajaran siswa dengan menggunakan model pembelajaran pendekatan kooperatif model 'Think Pair Share. Dalam model pembelajaran pendekatan kooperatif model 'Think Pair Share ini diawali guru memberikan penjelasan tentang hal-hal yang harus dipersiapkan untuk melakukan kegiatan. Kegiatan-kegiatan yang harus dilakukan oleh siswa dengan bimbingan guru adalah mulai dari merumuskan suatu permasalahan, mengamati atau melakukan observasi, menganalisis dan menyajikan hasil dalam tulisan, gambar, laporan, bagan, table, dan karya lainnya, serta siswa dilatih mengkomunikasikan atau menyajikan hasil karya pada orang lain. Setelah siswa memperoleh kejelasan tentang apa yang akan dilakukannya, guru mempersiapkan siswa untuk bekerja secara mandiri dengan kelompoknya dalam melakukan kegiatan pembelajaran.

Bersamaan dengan itu guru membimbing siswa melaui tahap-tahap pembelajarn secara runtut sampai menemukan solusi permasalahan yang dipilih oleh masing-masing kelompok. Kemudian tiap-tiap kelompok membuat hasil karya kelompok yang dipresentasikan di depan kelas atau melakukan diskusi kelas. Pada tahap ini peneliti 
mempersiapkan lembar observasi pengolahan pembelajaran koooperatif model Think Pair Share, dan lembar observasi aktivitas guru dan siswa.

2. Tahap Pelaksanaan

Pada tahap ini guru melakukan supervisi observasi kelas ke 5 Sekolah binaan sesuai jadwal yang telah ditetapkan. Kegiatan ini dilaksanakan selama 5 hari pada minggu I bulan Februari 2015. Dalam setiap kegiatan supervisi observasi kelas, dimulai dari peneliti mengikuti guru dalam menyajikan materi pembelajaran di kelas sesuai Rencana Pembelajaran yang telah disusun, yaitu kegiatan pembelajaran IPS dengan menggunakan pendekatan pembelajaran koooperatif model Think Pair Share, dengan tahapan mulai merumuskan suatu permasalahan, mengamati atau melakukan observasi, menganalisis dan menyajikan hasil dalam tulisan, gambar, laporan, bagan, table, dan karya lainnya, serta siswa dilatih mengkomunikasikan atau menyajikan hasil karya pada orang lain. Pada tahap ini siswa terasah dari berbagai kemampuan baik personal skill, academic skill, maupun social skill.

3. Tahap Pengamatan

Pada saat tahapan ini dilakukan, peneliti melakukan pengamatan kepada guru saat melakukan kegiatan pembelajaran IPS dengan model pembelajaran pendekatan koooperatif model Think Pair Share sesuai pokok bahasan yang direncanakan. Pengamatan dimulai ketika guru telah memberikan penjelasan dan motivasi-motivasi. Materi dan permasalahannya serta upaya mengatasinya dibahas oleh siswa dengan bimbingan guru melalui diskusi kelompok dan dilanjutkan diskusi kelas dengan menekankan pada kemampuan siswa untuk menemukan dan memecahkan masalah sesuai target pembelajaran pendekatan pembelajaran koooperatif model Think Pair Share. Adapun hasil pengamatan kepada guru dan siswa didapatkan aspek-aspek yang mendapatkan kriteria kurang baik adalah memotivasi siswa, pengelolaan waktu, dan siswa antusias. Ketiga aspek yang mendapat penilaian kurang baik di atas, merupakan suatu kelemahan yang terjadi pada siklus I. dan akan dijadikan bahan kajian untuk refleksi dan revisi yang akan dilakukan pada siklus II. Dari hasil pengamatan pada siklus I, bahwa rata-rata kemampuan guruguru di 5 Sekolah Binaan dalam menerapkan pembelajaran pendekatan kooperatif model think pair share adalah $51,6 \%$, yang berarti masih tergolong rendah. Hal ini nanti akan digunakan untuk bahan perbaikan pada pembelajaran siklus II. Disamping itu dalam pembelajaran pada siklus I ini peran guru masih cukup dominan untuk memberikan penjelasan dan arahan karena model tersebut masih dirasakan baru oleh siswa.

Hasil berikutnya adalah tes formatif siswa seperti terlihat pada tabel berikut :

Tabel 2. Hasil tes formatif siswa pada siklus 1

\begin{tabular}{lll}
\hline No & Uraian & Hasil siklus 1 \\
1 & Nilai rata-rata tes formatif & 70,45 \\
2 & Jumlah siswa yang tuntas belajar & 155 dari 220 siswa \\
3 & Persentase ketuntasan belajar & 70,45 \\
\hline
\end{tabular}

Dari tabel di atas dapat dijelaskan bahwa dengan menerapkan model pembelajaran kooperatif model Think Pair Share diperoleh nilai rata-rat prestasi belajar siswa adalah 70,45 dan ketuntasan belajar mencapai $70,45 \%$ atau ada 155 
siswa dari 220 siswa sudah tuntas belajar. Hasil tersebut menunjukkan bahwa pada siklus I secara klasikal siswa belum tuntas belajar, karena siswa yang memperoleh nilai $\geq 65$ hanya sebesar $70,45 \%$ lebih kecil dari prosentae ketuntasan yang dikehendaki yaitu sebesar $85 \%$. Hal ini disebabkan karena siswa masih merasa baru dan belum mengerti apa yang dimaksudkan dan digunakan guru dengan menerapkan model pembelajaran kooperatif model Think Pair Share.

4. Refleksi

Dalam pelaksanaan kegiatan belajar mengajar diperoleh informasi dari hasil pengamatan seperti berikut: (a) Guru kurang baik dalam memotivasi siswa dan dalam menyampaikan tujuan pembelajaran. (b) Guru kurang baik dalam pengelolaan waktu. (c) Siswa kurang begitu antusias selama pembelajaran berlangsung.

5. Revisi

Pelaksanaan kegiatan belajar mengajar pada siklus 1 ini masih terdapat kekurangan, sehingga perlu adanya revisi untuk dilakukan pada siklus berikutnya. (a) Guru perlu lebih terampil dalam memotivasi siswa dan lebih jelas dalam menyampaikan tujuan pebelajaran. Dimana siswa diajak untuk terlibat langsung dalam setiap kegiatan yang akan dilakukan. (b) Guru perlu mendistribusikan waktu secara baik dengan menambahkan informasi-informasi yang dirasa perlu dan memberi catatan. (c) Guru harus lebih terampil dan lebih bersemangat dalam memotivasi siswa sehingga siswa bisa lebih antusias.

\section{Siklus II}

\section{Tahap Perencanaan}

Pada kegiatan siklus II ini peneliti terlebih dahulu merencanakan pelaksanaan supervisi observasi kelas, dengan didahulu memberi penjelasan lagi kepada guru tentang konsep dan tahapan penerapan pembelajaran pendekatan kooperatif model
'Think Pair Share yang harus dilakukan oleh guru. Selanjutnya guru melaksanakan tahapan yang disarankan oleh peneliti, khususnya pada aspek-aspek yang masih kurang baik pada pelaksanaan pembelajaran siklus I. Selanjutnya dalam model pembelajaran pendekatan kooperatif model 'Think Pair Share pada siklus II ini diawali guru memberikan penjelasan tentang hal-hal yang harus dipersiapkan untuk melakukan kegiatan. Kegiatan-kegiatan yang harus dilakukan oleh siswa dengan bimbingan guru adalah mulai dari merumuskan suatu permasalahan, mengamati atau melakukan observasi, menganalisis dan menyajikan hasil dalam tulisan, gambar, laporan, bagan, table, dan karya lainnya, serta siswa dilatih mengkomunikasikan atau menyajikan hasil karya pada orang lain. Setelah siswa memperoleh kejelasan tentang apa yang akan dilakukannya, guru mempersiapkan siswa untuk bekerja secara mandiri dengan kelompoknya dalam melakukan kegiatan pembelajaran.

Bersamaan dengan itu guru membimbing siswa melaui tahap-tahap pembelajarn secara runtut sampai menemukan solusi permasalahan yang dipilih oleh masing-masing kelompok. Kemudian tiap-tiap kelompok membuat hasil karya kelompok yang dipresentasikan di depan kelas atau melakukan diskusi kelas. Pada tahap ini peneliti mempersiapkan lembar observasi pengolahan pembelajaran koooperatif model Think Pair Share, dan lembar observasi aktivitas guru dan siswa.

2. Tahap Pelaksanaan

Pada tahap ini guru melakukan supervisi observasi kelas ke 5 Sekolah binaan sesuai jadwal yang telah ditetapkan. Kegiatan ini dilaksanakan selama 5 hari pada minggu I bulan Maret 2015. Dalam setiap kegiatan supervisi observasi kelas, dimulai dari peneliti mengikuti guru dalam menyajikan materi pembelajaran di kelas sesuai Rencana 
Pembelajaran yang telah disusun, yaitu kegiatan pembelajaran IPS dengan menggunakan pendekatan pembelajaran koooperatif model Think Pair Share, dengan tahapan mulai merumuskan suatu permasalahan, mengamati atau melakukan observasi, menganalisis dan menyajikan hasil dalam tulisan, gambar, laporan, bagan, table, dan karya lainnya, serta siswa dilatih mengkomunikasikan atau menyajikan hasil karya pada orang lain. Pada tahap ini siswa terasah dari berbagai kemampuan baik personal skill, academic skill, maupun social skill.

3. Tahap Pengamatan

Pada saat tahapan ini dilakukan, peneliti melakukan pengamatan kepada guru saat melakukan kegiatan pembelajaran IPS dengan model pembelajaran pendekatan koooperatif model Think Pair Share sesuai pokok bahasan yang direncanakan. Pengamatan dimulai ketika guru telah memberikan penjelasan dan motivasi-motivasi. Materi dan permasalahannya serta upaya mengatasinya dibahas oleh siswa dengan bimbingan guru melalui diskusi kelompok dan dilanjutkan diskusi kelas dengan menekankan pada kemampuan siswa untuk menemukan dan memecahkan masalah sesuai target pembelajaran pendekatan pembelajaran koooperatif model Think Pair Share. Adapun hasil pengamatan kepada guru dan siswa didapatkan aspek-aspek yang mendapatkan kriteria kurang baik pada siklus II adalah pada aspek memotivasi siswa, dan pengelolaan waktu, sedang aspek siswa antusias sudah mengalami kenaikan yang cukup berarti. Kedua aspek yang mendapat penilaian kurang baik di atas, merupakan suatu kelemahan yang terjadi pada siklus II. dan akan dijadikan bahan kajian untuk refleksi dan revisi yang akan dilakukan pada siklus III. Dari hasil pengamatan pada siklus II, bahwa rata-rata kemampuan guru-guru di 5 Sekolah Binaan dalam menerapkan pembelajaran pendekatan kooperatif model think pair share adalah $72,4 \%$, yang berarti sudah tergolong baik, namun demikian belum sesuai dengan tujuan dilaksanakannya PTS ini, sehingga masih perlu dilakukan lagi pembelajaran pada siklus III. Disamping itu dalam pembelajaran pada siklus II ini dominasi guru sudah berkurang untuk memberikan penjelasan.

Hasil berikutnya adalah tes formatif siswa seperti terlihat pada tabel berikut :

Tabel 3. Hasil tes formatif siswa pada siklus II

\begin{tabular}{lll}
\hline No & Uraian & Hasil siklus II \\
1 & Nilai rata-rata tes formatif & 75,68 \\
2 & Jumlah siswa yang tuntas belajar & 180 dari 220 siswa \\
3 & Persentase ketuntasan belajar & 81,82 \\
\hline
\end{tabular}

menginformasikan bahwa setiap akhir pelajaran akan selalu diadakan tes sehingga pada pertemuan berikutnya siswa lebih termortivasi untuk belajar. Selain itu siswa juga sudah mulai mengerti apa yang dimaksudkan dan diinginkan guru dengan menerapkan metode pembelajaran kooperatif model Think Pair Share

4. Tahap Refleksi

Dalam pelaksanaan kegiatan ketuntasan belajar secara klasikal telah mengalami peningkatan sedikit lebih baik dari siklus I. Adanya peningkatan hasil belajara siswa ini karena setelah guru belajar mengajar diperoleh informasi dari hasil pengamatan seperti berikut: (a) Memotifasi siswa, (b) Membimbing siswa 
merumuskan kesimpulan/menemukan konsep, (c) Pengelolaan waktu

\section{Revisi Rancangan}

Pelaksanaan kegiatan belajar mengajar pada siklus II ini masih terdapat kekurangan-kekurangan. Maka perlu adanya revisi untuk dilakukan pada siklus III antara lain: (a) Guru dalam memotivasi siswa hendaknya dapat membuat siswa lebih termotivasi selama proses belajar mengajar berlangsung. (b) Guru harus lebih dekat dengan siswa sehingga tidak ada perasaan takut dalam diri siswa baik untuk mengemukakan pendapat atau bertanya. (c) Guru harus lebih sabar dalam membimbing siswa merumuskan kesimpulan/menemukan konsep. (d) Guru harus mendistribusikan waktu secara baik sehingga kegiatan pembelajran dapat berjalan sesuai dengan yang diharapkan. (d) Guru sebaiknya menambah lebih banyak contoh soal dan memberi soal-soal latihan pada siswa untuk dikerjakan pada setiap kegiatan belajar mengajar.

\section{Siklus III}

1. Tahap Perencanaan

Pada kegiatan siklus III ini peneliti terlebih dahulu merencanakan pelaksanaan supervisi observasi kelas, dengan didahulu memberi penjelasan lagi kepada guru tentang konsep dan tahapan penerapan pembelajaran pendekatan kooperatif model 'Think Pair Share yang harus dilakukan oleh guru. Selanjutnya guru melaksanakan tahapan yang disarankan oleh peneliti, khususnya pada aspek-aspek yang masih kurang baik pada pelaksanaan pembelajaran siklus II. Selanjutnya dalam model pembelajaran pendekatan kooperatif model 'Think Pair Share pada siklus III ini diawali guru memberikan penjelasan tentang hal-hal yang harus dipersiapkan untuk melakukan kegiatan. Kegiatan-kegiatan yang harus dilakukan oleh siswa dengan bimbingan guru adalah mulai dari merumuskan suatu permasalahan, mengamati atau melakukan observasi, menganalisis dan menyajikan hasil dalam tulisan, gambar, laporan, bagan, table, dan karya lainnya, serta siswa dilatih mengkomunikasikan atau menyajikan hasil karya pada orang lain. Setelah siswa memperoleh kejelasan tentang apa yang akan dilakukannya, guru mempersiapkan siswa untuk bekerja secara mandiri dengan kelompoknya dalam melakukan kegiatan pembelajaran.

Bersamaan dengan itu guru membimbing siswa melaui tahap-tahap pembelajarn secara runtut sampai menemukan solusi permasalahan yang dipilih oleh masing-masing kelompok. Kemudian tiap-tiap kelompok membuat hasil karya kelompok yang dipresentasikan di depan kelas atau melakukan diskusi kelas. Pada tahap ini peneliti mempersiapkan lembar observasi pengolahan pembelajaran koooperatif model Think Pair Share, dan lembar observasi aktivitas guru dan siswa.

2. Tahap Pelaksanaan

Pada tahap ini guru melakukan supervisi observasi kelas ke 5 Sekolah binaan sesuai jadwal yang telah ditetapkan. Kegiatan ini dilaksanakan selama 5 hari pada minggu I bulan April 2015. Dalam setiap kegiatan supervisi observasi kelas, dimulai dari peneliti mengikuti guru dalam menyajikan materi pembelajaran di kelas sesuai Rencana Pembelajaran yang telah disusun, yaitu kegiatan pembelajaran IPS dengan menggunakan pendekatan pembelajaran koooperatif model Think Pair Share, dengan tahapan mulai merumuskan suatu permasalahan, mengamati atau melakukan observasi, menganalisis dan menyajikan hasil dalam tulisan, gambar, laporan, bagan, table, dan karya lainnya, serta siswa dilatih mengkomunikasikan atau menyajikan hasil karya pada orang lain. Pada tahap ini siswa terasah dari berbagai kemampuan baik personal skill, academic skill, maupun social skill. 


\section{Tahap Pengamatan}

Pada saat tahapan ini dilakukan, peneliti melakukan pengamatan kepada guru saat melakukan kegiatan pembelajaran IPS dengan model pembelajaran pendekatan koooperatif model Think Pair Share sesuai pokok bahasan yang direncanakan. Pengamatan dimulai ketika guru telah memberikan penjelasan dan motivasi-motivasi. Materi dan permasalahannya serta upaya mengatasinya dibahas oleh siswa dengan bimbingan guru melalui diskusi kelompok dan dilanjutkan diskusi kelas dengan menekankan pada kemampuan siswa untuk menemukan dan memecahkan masalah sesuai target pembelajaran pendekatan pembelajaran koooperatif model Think Pair Share. Adapun hasil pengamatan kepada guru dan siswa didapatkan aspek-aspek yang mendapatkan kriteria kurang baik pada siklus III sudah tidak ada, dan hanya satu aspek yang mendapatkan rata-rata cukup yaitu pada aspek memotivasi siswa, sedang aspek lainnya semua mendapatkan nilai baik. Hal ini menunjukkan bahwa kemampuan guruguru di Sekolah Binaan telah mengalami kenaikan dari siklus ke siklus. Dari hasil pengamatan pada siklus III, bahwa ratarata kemampuan guru-guru di 5 Sekolah Binaan dalam menerapkan pembelajaran pendekatan kooperatif model think pair share adalah $86,60 \%$, yang berarti sudah tergolong baik, dan bahkan sudah mendekati tercapainya tujuan diadakannya PTS ini., sehingga sudah tidak diperlukan lagi pembelajaran pada siklus IV.

Hasil berikutnya adalah tes formatif siswa seperti terlihat pada tabel berikut :

Tabel 4. Hasil Tes Formatif Siswa pada Siklus III

\begin{tabular}{lll}
\hline No & Uraian & Hasil siklus III \\
1 & Nilai rata-rata tes formatif & 82,27 \\
2 & Jumlah siswa yang tuntas belajar & 195 dari 220 siswa \\
3 & Persentase ketuntasan belajar & 88,64 \\
\hline
\end{tabular}

Berdasarkan tabel di atas diperoleh nilai rata-rat tes formatif sebesar 82,27 dan dari 220 siswa yang telah tuntas sebanyak 195 siswa dan 25 siswa belum mencapai ketuntasan belajar. Maka secara klasikal ketuntasan belajar yang telah tercapai sebesar $88,64 \%$ (termasuk kategori tuntas). Hasil pada siklus III ini mengalami peningkatan lebih baik dari siklus II. Adanya peningkatan hasil belajara pada siklus III ini dipengaruhi oleh adanya peningkatan kemampuan guru dalam menerapkan pembelajaran kooperatif model Think Pair Share sehingga siswa menjadi lebih terbiasa dengan pembelajaran seperti ini sehingga siswa lebih mudah dalam memahami meteri yang telah diberikan.

\section{Refleksi}

Pada tahap ini akan dikaji apa yang telah terlaksana dengan baik maupun yang masih kurang baik dalam proses belajar mengajar dengan penerapan pembelajaran kooperatif model Think Pair Share. Dari data-data yang telah diperoleh dapat diuraikan sebagai berikut: (a) Selama proses belajara mengajar guru telah melaksanakan semua pembelajaran dengan baik. Meskipun ada beberapa aspek yang belum sempurna, tetapi persentase pelaksanaannya untuk mesing-masing aspek cukup besar. (b) Berdasarkan data hasil pengamatan diketahui bahwa siswa aktif selama proses belajar mengajar berlangsung. (c) Kekurangan pada siklussiklus sebelumnya sudah mengalami perbaikan dan peningkatan sehingga menjadi lebih baik. (d) Hasil belajar siswa pada siklus III mencapai ketuntasan.

4. Revisi pelaksanaan

Pada siklus III ini telah menerapkan pembelajaran kooperatif model Think Pair Share dengan baik dan 
dilihat dari aktivitas siswa serta hasil belajar siswa pelaksanaan proses belajar mengajar sudah berjalan dengan baik. Maka tidak perlu adanya revisi terlalu banyak, tetapi yang perlu diperhatikan untuk tindakan selanjutnya adalah memaksimalkan dan mempertahankan apa yang telah ada dengan tujuan agar pada pelaksanaan proses belajar mengajar selanjutnya penerapan pembelajaran kooperatif model Think Pair Share dapat meningkatkan proses belajar mengajar sehingga tujuan pembelajaran dapat tercapai.

Disamping hasil pengamatan terhadap kemampuan guru dalam menerapkan pembelajaran Kooperatif model think pair share, berikut ini ditampilkan hasil angket yang diberikan pada siswa setelah siswa melaksanakan proses pembelajaran dengan metode pembelajaran kooperatif model Think Pair Share (siklus III). Jumlah pertanyaan dalam angket sebanyak 36 butir dan jumlah responden sebanyak 220 siswa, untuk mengetahui tanggapan siswa terhadap metode pembelajaran kooperatif model Think Pair Share. Hasil analisis angket motivasi siswa menunjukkan bahwa tanggapan siswa terhadap metode pembelajaran kooperatif model Think Pair Share adalah, positif. Berdasarkan jumlah rata-rata dalam persen menunjukkan bahwa $80 \%$ siswa setuju dengan kegiatan pembelajaran kooperatif model Think Pair Share, 63\% setuju dengan materi yang diajarkan dengan metode pembelajaran kooperatif model Think Pair Share, 53\% setuju dengan kegiatan kerja kelompok yang dilaksanakan dalam pembelajaran kooperatif model Think Paie Share, dan 73\% siswa setuju dengan penggunaan LKS dalam kegiatan pembelajaran kooperatif model Think Pair Share. Dari hasil penelitian tersebut diperoleh pembahasan sebagai berikut:

1. Kemampuan guru dalam mengelola pembelajaran
Berdasarkan analisis data, diperoleh aktivitas siswa dalam proses pembelajaran kooperatif Think Pair Share dalam setiap siklus mengalami peningkatan, yaitu dari rata $51,6 \%$ pada siklus I, dan pada siklus II naik menjadi $72,4 \%$, serta pada siklus III menjadi $86,60 \%$. Hal ini berdampak positif terhadap prestasi belajar siswa yaitu dapat ditunjukkan dengan meningkatnya nilai rata-rata siswa pada setiap siklus yang terus mengalami peningkatan.

Sedangkan untuk aktivitas guru selama pembelajaran telah melaksanakan langkah-langkah pembelajaran kooperatif model Think Pair share dengan baik. Hal ini terlihat dari aktivitas guru yang muncul diantaranya aktivitas membimbing dan mengamati siswa dalam mengerjakan kegiatan LKS/menemukan konsep, menjelaskan materi yang sulit, memberi umpan balik / evaluasi / tanya jawab dimana prosentase untuk aktivitas di atas cukup besar.

2. Ketuntasan hasil belajar siswa

Melalui hasil penelitian ini menunjukkan bahwa pembelajaran kooperatif model Think Pair Share memiliki dampak positif dalam meningkatkan prestasi belajar siswa. Hal ini dilihat dari semakin mantapnya pemahaman siswa terhadap materi yang disampaikan guru (ketuntasan belajar meningkat dari siklus I, II, dan III) yaitu masing-masing $70,45 \%, 81,82 \%$, dan $88,64 \%$. Pada siklus III ketuntasan belajar siswa secara klasikal telah tercapai.

3. Tanggapan siswa terhadap Metode pembelajaran kooperatif model Think Pair Share

Berdasarkan analisis angket siswa dapat diketahui bahwa tanggapan siswa termasuk positif. Ini ditunjukkan dengan rata-rata jawaban siswa yang menyatakan bahwa siswa tertarik dan berminat dengan metode pembelajaran kooperatif model Think Pair Share. Hal ini menunjukkan bahwa siswa memberikan respon positif 
metode pembelajaran kooperatif model Think Pair Share, sehingga siswa menjadi termotivasi untuk belajar lebih giat. Jadi dapat disimpulkan bahwa dengan diterapkannya metode pembelajaran model Think Pair Share dapat meningkatkan motivasi belajar siswa.

Berdasarkan data sebelumnya, maka hipotesis yang diajukan dalam pendahuluan, dapat diterima. Hipotesis itu terbukti setelah diadakan penelitian/observasi selama 3 siklus. Bunyi hipotesisnya adalah "Dengan melakukan supervisi observasi kelas oleh pengawas sekolah mampu meningkatkan kemampuan dan ketrampilan guru dalam mengelola pembelajaran pendekatan kooperatif model Think Pair Share pada sekolah binaan kabupaten Lamongan". Sebagai gambaran untuk memperjelas keberhasilan PTS ini, dapat kita lihat tabel dan grafik perbandingan antara kemampuan guru-guru di 5 Sekolah Binaan sebelum PTS dan setelah siklus III di bawah ini:

Tabel 5. Perbandingan Kemampuan Guru-guru di 5 Sekolah Binaan Dalam Menerapkan Pembelajaran Kooperatif Model Think Pair Share antara Siklus I, II, dan III

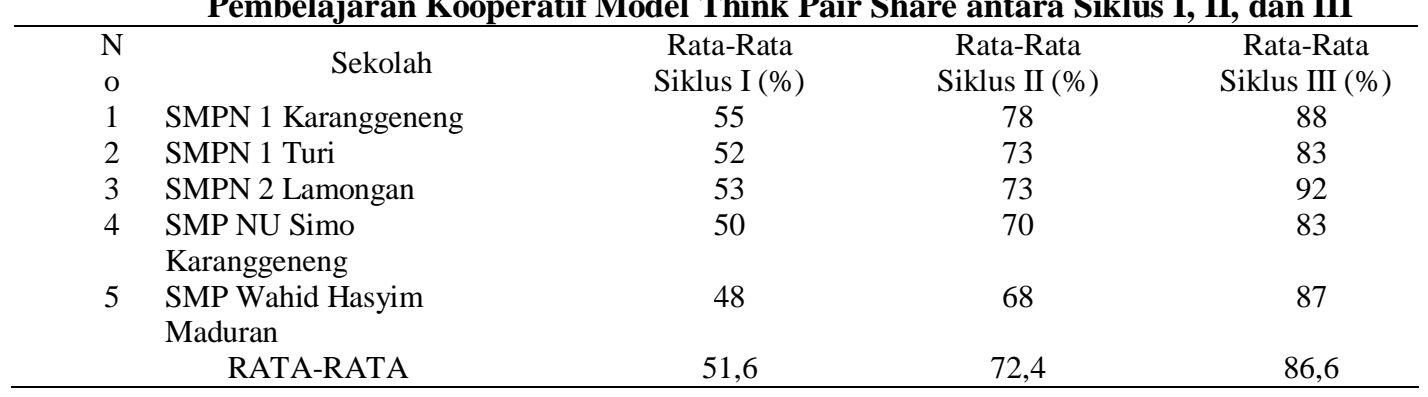

Dari data di atas dapat digambarkan dalam diagram batang sebagaimana di bawah ini:

Grafik Perbandingan Kemampuan Guru Sekolah Binaan Antara Siklus I, II,dan III

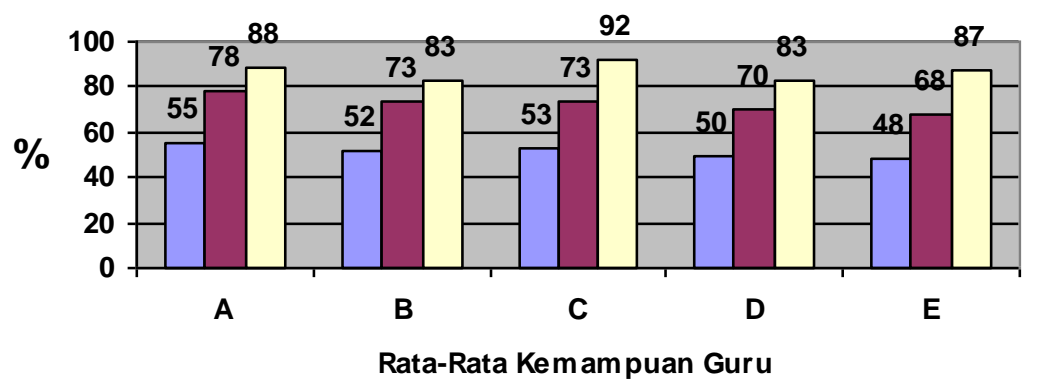

$\square$ Siklus I $\square$ Siklus II $\square$ Siklus III 


\section{KESIMPULAN}

Dari hasil kegiatan pembelajaran yang telah dilakukan selama tiga siklus, dan berdasarkan seluruh pembahasan serta analisis yang telah dilakukan dapat disimpulkan sebagai berikut: (1) Teknik supervisi observasi kelas yang dilakukan peneliti/pengawas sekolah sebanyak 3 siklus, mampu meningkatkan kemampuan para guru IPS di 5 Sekolah Binaan kabupaten Lamongan dalam mengelola pembelajaran kooperatif model Think Pair Share. Hal ini dibuktikan dengan kemampuan guru pada siklus I yang hanya $51,6 \%$ naik menjadi $72,4 \%$ pada siklus II, dan menjadi $86,6 \%$ pada siklus III. (2) Pembelajaran dengan kooperatif model Think Pair Share memiliki dampak positif dalam meningkatkan prestasi belajar siswa yang ditandai dengan peningkatan ketuntasan belajar siswa dalam setiap siklus, yaitu siklus I $(70,45 \%)$, siklus II $(81,82 \%)$, dan siklus III $(88,64 \%)$. (3) Penerapan model pembelajaran kooperatif model Think Pair Share mempunyai pengaruh positif, yaitu dapat meningkatkan motivasi belajar siswa yang ditunjukkan dengan rata-rata jawaban siswa yang menyatakan bahwa siswa tertarik dan berminat dengan model pembelajaran kooperatif Think Pair Share sehingga mereka menjadi termotivasi untuk belajar.

\section{DAFTAR PUSTAKA}

Felder, Richard M. 2004. Cooperative Learning in Technical Corse, $(\mathrm{On}$ line), (Pcll/d/My \%

Document/Coop \% 20 Report. Htm, diakses 10 Juni 2004).

Kemdiknas (2013) Standar Isi Untuk Satuan Pendidikan Dasar dan Menengah, Kemdiknas Jakarta.

Margono, S. 2006. Metodologi Penelitian

Pendidikan. Jakarta: Rineksa Cipta.
Nur, Muhammad. 2006. Pembelajaran Kooperatif. Surabaya. Universitas Negeri Surabaya.

Soetomo. 2013. Dasar-dasar Interaksi Belajar Mengajar. Surabaya Usaha Nasional.

Sudjana. 2006. Metode Statistik. Bandung: Tarsito.

Sudjana, N dan Ibrahim. 2009. Penelitian dan Penilaian Pendidikan. Bandung: Sinar Baru.

Undang-undang Republik Indonesia No. 20 tahun 2003 tentang Sitem Pendidikan Nasional (SISDIKNAS). 2003. Bandung: Citra Umbaran.

Wahyuni, Dwi. 2011. Studi tenang Pmbelajaran Kooperatif terhadap hasil belajar. Malang: Program Sarjana Universitas Negeri Malang. 